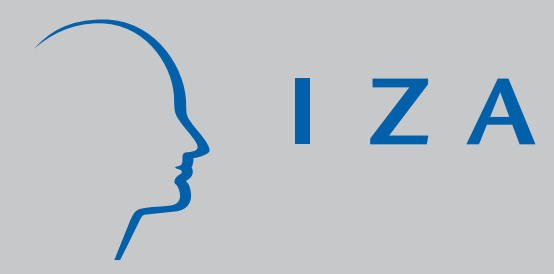

IZA DP No. 3599

Should You Compete or Cooperate with Your Schoolmates?

Massimiliano Bratti

Daniele Checchi

Antonio Filippin

J uly 2008 


\title{
Should You Compete or Cooperate with Your Schoolmates?
}

\author{
Massimiliano Bratti \\ University of Milan and IZA \\ Daniele Checchi \\ University of Milan and IZA \\ Antonio Filippin \\ University of Milan and IZA
}
Discussion Paper No. 3599
July 2008

IZA
P.O. Box 7240
53072 Bonn
Germany

Phone: +49-228-3894-0

Fax: +49-228-3894-180

E-mail: iza@iza.org

\begin{abstract}
Any opinions expressed here are those of the author(s) and not those of IZA. Research published in this series may include views on policy, but the institute itself takes no institutional policy positions.

The Institute for the Study of Labor (IZA) in Bonn is a local and virtual international research center and a place of communication between science, politics and business. IZA is an independent nonprofit organization supported by Deutsche Post World Net. The center is associated with the University of Bonn and offers a stimulating research environment through its international network, workshops and conferences, data service, project support, research visits and doctoral program. IZA engages in (i) original and internationally competitive research in all fields of labor economics, (ii) development of policy concepts, and (iii) dissemination of research results and concepts to the interested public.
\end{abstract}

IZA Discussion Papers often represent preliminary work and are circulated to encourage discussion. Citation of such a paper should account for its provisional character. A revised version may be available directly from the author. 


\begin{abstract}

\section{Should You Compete or Cooperate with Your Schoolmates?}

Building upon some education studies finding that cooperative behaviour in class yields better achievements among students, this paper presents a simple model showing that free riding incentives lead to an insufficient degree of cooperation between schoolmates, which in turn decreases the overall achievement. A cooperative learning approach may instead emerge when competitive behaviour is negatively evaluated by schoolmates, especially when the class is more homogeneous in terms of students' characteristics (e.g., ability). Empirical evidence supporting our model is found using the 2003 wave of the OECD Programme for International Student Assessment (PISA) survey on students' literacy levels. A competitive learning approach has a positive individual return (higher in comprehensive educational systems), while student performance increases with the average cooperative behaviour, particularly in tracked educational systems.
\end{abstract}

JEL Classification: I21, J24

Keywords: cooperation, competition, PISA, student attitudes

Corresponding author:

Antonio Filippin

Department of Economics

University of Milan

Via Conservatorio 7

20122 Milano

Italy

E-mail: antonio.filippin@unimi.it

\footnotetext{
* We would like to thank Vasilis Koulaidis (Dept. Education, University of Athens) for helpful suggestions. We also thank the participants to the "4th Symposium of the Network Economics of Education and Education Policy in Europe" (Madrid), to the conference "Education, Equity and Social Justice" (Prague) and to the seminars held at the University of Milan and at the University of Bolzano for their comments. The usual disclaimer applies.
} 


\section{Introduction}

Educational research can be broadly distinguished into two main bodies. The first one treats schooling as something that is done to students rather than something that is done by students, as in the education economics literature that estimates educational production functions (see Monk, 1990). Students are considered as the "raw material" that is combined with other inputs (typically school resources) into the educational production function to produce an output that is often measured in terms of schooling attainment or school grades. Hence, students are given a completely passive role and little insight is given on the importance of student behaviour and student attitudes for educational outcomes. On the other extreme, the second type of research, which will be partly reviewed below, is largely psychological and pedagogical and often based on case studies that put the student and the teacher at the core of the learning process and that typically refuse any generalisation across students, schools or countries.

In this paper we try to bridge the two streams of literature. From the pedagogical and psychological literature we borrow the idea of the centrality of student's attitudes and behaviours in the learning process. Starting from the educationalist's research that found a positive relation between group-learning and knowledge, we investigate the theoretical implications of students' competitive and cooperative behaviours for learning. At the same time we use a research tool typical of education economists, i.e. the "educational production function" and an approach based on the investigation of large data sets rather than of small case studies. We use data from the 2003 wave of the OECD's Programme for International Student Assessment (PISA), which gathers comparable information on students enrolled in several schools located in many different countries and provides a standardized measure of student competences (our proxy of learning). Despite the disadvantage of requiring a higher degree of generalization because we have much less information on the group than in case studies, we think that a large scale survey offers nonetheless some clear advantages such as the opportunity to investigate empirical regularities that go beyond a single class or a single school.

While economists did not analyze the learning process from the student's cooperation-competition point of view, the educationalists' research on the matter is rather extensive. We summarize here some of their contributions, with the main purpose of stressing the findings that are also relevant from an economic point of view. ${ }^{1}$

The learning process is affected both by intrinsic and by extrinsic motivation. The latter comes from the external environment, out of the person, who acts with the anticipation of punishments and rewards, such as getting teacher and peer

\footnotetext{
${ }^{1}$ See Abrami et al. (2000) and Watkins (2005) for a thorough review of the literature. Strijbos and Fischer (2007) discuss methodological issues in interdisciplinary research on collaborative learning.
} 
praise, acquiring a good grade, obtaining parental reward. For instance, earning high marks may enhance learning whenever marks are important to students as signals for either the continuation of the educational career, or for a potential employers in the labour market. In contrast, intrinsic motivation occurs when the learning activity and the learning environment per se elicit motivation, because the student finds studying enjoyable and acquiring knowledge is a reward by itself. According to Malone and Lepper (1987), the factors that enhance intrinsic motivation can be divided into individual factors (e.g. curiosity) and interpersonal ones (e.g. feeling satisfaction by helping others, or when others recognize and appreciate one's accomplishments).

Educationalists usually consider intrinsic motivation as more effective than the extrinsic one in enhancing the acquisition of knowledge, and in a parallel fashion they regard group learning as more effective than individual learning. For instance, Shachar and Fischer (2004) claim that group investigation is "designed to enhance intrinsic motivation by virtue of its emphasis on a high level of student autonomy and responsibility in making decisions regarding the selection and implementation of study projects [...], as well as receiving and offering considerable support from, and assistance to, group-mates". In addition, group work requires caring for others, thus reinforcing the sense of community belonging. ${ }^{2}$ Discussing with classmates involves reconciliation of multiple perspectives through the medium of dialogue, and this collaboration develops a higher abstraction and elaboration skills.

Moreover, group activity allows for individualised attention for low achieving students, as well as providing an opportunity to high achievers to improve their understanding of the subject while illustrating it to the group. In group learning students of different abilities obtain a personalised motivation, provided that group composition does not mix extremes that are too far apart. Students with different levels of achievement appreciate differently group learning. Rather common in this stream of literature are the findings that low achievers seem to gain more from group learning than high achievers, ${ }^{3}$ and that high achievers are more inclined to gain recognition of their level of ability through competition in the class. ${ }^{4}$ All these features characterize also the model that is presented in the next section.

Increasing empirical evidence suggests that group learning yields superior outcomes in terms of student's motivation and achievement. Whatever teaching technique is adopted in a class, and irrespective of students' age or subject

\footnotetext{
2 See for instance Watkins (2005) and Cowie and Berdondini (2001).

${ }^{3}$ Hoek et al (1999) reports a mathematical reasoning test conducted among $7^{\text {th }}$ grade students, where high achievers benefited more than low achievers (differential effect), but the same outcome was reversed in other types of tests. Low achievers seem also benefit from additional attention from the teacher under group learning (remedial effect).

${ }^{4}$ See Shachar and Fischer (2004), p.83.
} 
taught, most literature stresses the advantages of cooperative learning. ${ }^{5}$ According to the advocates of this approach, the main advantage of passing from a teacher-centred learning (namely "learning = being taught") to group learning is exactly the appeal to individual intrinsic motivation for learning ("learning = individual sense-making", according to Watkins, 2005).

Cooperative learning, however, is not a spontaneous phenomenon:

\begin{abstract}
Effective group work requires students to share ideas, take risks, disagree with and listen to others, and generate and reconcile points of view. These norms do not necessarily pervade classrooms. Students are used to working individually, being rewarded for right answers, and competing with each other for grades. Placing students in groups does not mean they will actually cooperate. There is considerable and disturbing evidence that students often do not behave pro-socially. One problem is failure to contribute. When groups create a single product and receive one grade, students sometimes do not do their fair share. (Blumenfeld et al., 1996, p.38).
\end{abstract}

As the quotation makes it clear, groups work according to implicit or explicit norms that regulate individual contributions and individual accountability is essential to ensure a generalised participation to cooperation.

As economists, not only we are particularly sensitive to the caveat raised by the quotation above, but we are also tempted to stress the role of explicit incentives as represented by extrinsic motivations. Summarizing the previous literature we cannot miss the strong similarities that learning in groups has with the provision of public goods. Group learning (the public good) has positive externalities, since all students seem to improve their achievements. However, individual incentives favour free riding and these incentives are increasing in student's ability, since the most brilliant students are those who contribute more to group learning, with a greater benefit for the "worst" (i.e., the less able) ones. Group norms may reverse individual incentives, but they are strongly dependent on the environment. In fact, the emergence of cooperation is influenced by the sociocultural environment where learning takes place. The environment shapes the incentives and the attitudes of participants, rewards or penalises the leaders, reinforces or weakens stereotypes.

In the sequel we expand this line of argument by proposing a model where each student allocates her effort between two types of activity, cooperation or competition. Cooperation may be thought to correspond to group learning, providing positive externalities in terms of knowledge to the entire group of students irrespective of individual contribution. Competition has a private return only, which is increasing in ability. As a consequence, under spontaneous

5 Zammuner (1995) reports evidence of text quality of individual writing Vs. dyadic writing/revision in an experiment conducted among $4^{\text {th }}$ graders. She finds higher quality improvement under individual writing and dyadic revision. Hanze and Berger (2007) study the impact of the jigsaw cooperative learning method (i.e. when each student is assigned a specific task in group activity) in $12^{\text {th }}$ grade physics classes, showing positive effects on intrinsic motivation, experience of competence (especially among low achievers) and activation of deeper level processing. 
ordering there is an excess of competition and limited cooperation. However, when group norms are modified (for instance because a teacher may favour group learning or because peers penalize selfish behaviour), these conclusions can be reversed.

In the second part of the paper, we bring the theoretical predictions of the model to the data, using the PISA 2003 survey, where students self-declare their learning attitudes towards cooperation and competition. Although such a dataset does not allow to observe the process that effectively occurs in class, it has the great advantage of providing a large scale analysis based on a standardized measure of performance, while the pedagogical and psychological literature usually rely on small case studies. We study the correlation between students' attitudes and performance, showing that there is an individual incentive to be competitive, but a group advantage in adopting cooperative strategies.

The structure of the paper is as follows. In Section 2 we present a model that frames cooperation and competition in learning, providing some testable theoretical predictions. In Section 3 we provide some empirical evidence drawn from an international student survey, which contains information about student learning attitudes and performance. Section 4 concludes.

\section{Theoretical Framework}

The relative performance within one's school is a useful signal of students' abilities, which certainly affects their likelihood of finding a good job. However, such a signal is imperfect, and the employers adopt other devices, like interviews, to compare candidates who often come from different schools. There are therefore two components that are salient in this framework. The first is a relative component, i.e. the knowledge acquired in comparison with the students coming from the same school, as certified by the final grade. The second is an absolute component, not captured by the relative ranking, that needs to be evaluated in order to compare students coming from different schools.

Many studies in education, psychology and economics document how children may be more clearly motivated by short-run gratification (corresponding to a relative performance) rather than less tangible long-run rewards (which can be assimilated to an absolute performance - see Chelonis, Flake, Baldwin, Blake and Paule 2004, Harbaugh and Krause 1998, Bettinger and Slonim 2006). However, in what follows we focus on the absolute level of knowledge, thereby assuming that students encompass the long run consequences of their choices. Such a framework, which turns out to be much simpler from the algebraic point of view, defines a lower bound to competition. If we were to assume that students also care about being in the highest possible position in the ladder, we would stress more their incentives to compete, without changing the main implications of the model. 


\subsection{The Production of Knowledge}

We assume that each student cares about her optimal level of knowledge, which can be produced privately (through individual learning activities) or collectively (through group learning).

The simplest way to model the decision of time allocation is to consider that learning has an opportunity cost which is identical among students, and for simplicity described by a quadratic disutility function. On the contrary, the choice between individual or group learning requires clarifying the production process of knowledge.

In what follows, we partly deviate from the educational literature previously outlined, which views "cooperative learning" as that mainly taking place in class and induced by teachers. Indeed, we adopt a different and broader concept of "cooperative learning" (or "group learning"), which refers to situations where students are free to choose how to allocate their time and whether to work alone or in groups. Therefore, it mainly applies to study time outside class hours, including for instance student homework done in group.

We assume that private knowledge is produced through individual learning. This requires not sharing knowledge acquisition with classmates, possibly to be recognised as better than others in class. ${ }^{6}$ Symmetrically, we assume that public knowledge is achieved through learning in a group, which necessarily requires sharing knowledge with others. An example can be described by fluency in language. Private knowledge occurs whenever a student learns the meaning of a specific word on her own. We speak of private knowledge even if the word is known by a group of students, or by the whole class, provided that every student has learned the word without interacting with her classmates. Public knowledge instead corresponds to the case where an entire class can use a specific word thanks to group interaction. Another example is given by homework: the time students spend solving their assignments individually enters the definition of effort devoted to the production of private knowledge. In contrast, if students work in groups, what they learn by doing homework is classified as public knowledge.

The crucial issue in our model is how students' time is allocated between individual learning (production of private knowledge) and group learning (production of public knowledge). We face here the usual free riding problem: everybody has the incentive to allocate the maximum amount of time to the

\footnotetext{
${ }^{6}$ For the sake of simplicity in the theoretical model we adopt as the relevant student's community a class. However, group learning (or cooperative learning) may also take place among students from different classes but from the same school, especially when we consider student homework. In fact, due to the nature of the data used in the empirical analysis (OECD PISA) we will consider a school as the relevant student community. Alternatively, one might assume that classes' behaviours are homogenous within the same school.
} 
acquisition of private knowledge, while hoping that at the same time all the other fellow students invest enough time producing public knowledge. Using one of the aforementioned examples, this corresponds to a student participating in group work only to get the solutions of the homework costly elaborated by her classmates, and then spending most of her time studying alone in order to get higher marks. The underlying reason is that the time devoted to group learning has a small individual return, since it is diluted among all the participants. The higher the number of students, the lower the individual return on time spent producing public knowledge (e.g., because larger communities makes it more difficult individual interaction). In the limit case where there is a continuum of agents and the individual contribution is negligible, the optimal contribution to the production of public knowledge is equal to zero (which we can indicate as a "purely competitive outcome").

The simplest way of formalizing such a framework is the following:7

$$
U_{i}=\alpha_{i} p_{i}+\tilde{s}-\frac{1}{2}\left(p_{i}\right)^{2}-\frac{1}{2}\left(s_{i}\right)^{2}
$$

where $U_{i}$ is individual utility, $p_{i}$ is the time devoted to individual learning by student $i$, whose ability is $\alpha_{i}$. The interaction $\alpha_{i} p_{i}$ represents what we term private knowledge, i.e. what students learn on their own. The time devoted to group learning $\left(s_{i}\right)$ generates instead public knowledge $(\tilde{s})$, defined as

$$
\tilde{s}=\frac{1}{\sigma_{\alpha} n} \sum_{i=1}^{n} \alpha_{i} s_{i}
$$

We assume that the production of public knowledge is decreasing in students' heterogeneity as represented by the standard deviation of their ability $\left(\sigma_{\alpha}\right)$. The underlying idea is that peer effects are more intense in more homogenous environments. Therefore, mixing extremes that are too far apart implies a loss in terms of knowledge on both sides: the best students waste (part of) their time

\footnotetext{
${ }^{7}$ Identical results are obtained by means of a Cobb-Douglas utility function subject to an explicit time constraint, provided that the exponents are chosen appropriately (in order to obtain meaningful results) and that the upper bound of the distribution of ability is kept sufficiently low to ensure a positive amount of leisure. In that case the solutions for $p^{*}$ and $s^{*}$ can be interpreted as the fraction of time devoted to each type of learning. Notice also that in the specification adopted above, it makes a significant difference whether the disutility of learning is modelled separately for private and public knowledge, or instead considering the sum of the time devoted to both tasks. If a student cares only about the total time spent studying, but she is indifferent about its allocation between individual or group learning, the outcome will be a corner solution where she spends her time only on the task yielding the highest marginal return. In contrast, modelling two separate costs allows internal solutions to emerge, because it implies that students prefer to diversify time allocation between the two activities. We regard this as a more appropriate model, since we rarely observe students adopting extreme behaviours like "pure competitor" or "pure cooperator".
} 
interacting with the least brilliant students, if the latter do not fully grasp the arguments put forward by the former.

Moreover, for group learning to have a fostering effect on total knowledge, it is necessary that the output is higher than the sum of the inputs: we have to make sure that $\sigma_{\alpha}<1$. This happens, for instance, when ability is uniformly distributed over a unitary support (i.e. $\alpha \approx U[0,1]$ ), which also has the great advantage of simplifying the algebra.

From the first order conditions the following optimal choices emerge:

$$
\begin{gathered}
\underset{p_{i}}{\arg \max }\left[U_{i}\right]=p_{i}^{*}=\alpha_{i} \\
\underset{s_{i}}{\arg \max }\left[U_{i}\right]=s_{i}^{*}=\frac{\alpha_{i}}{\sigma_{\alpha} n}
\end{gathered}
$$

with the contribution to public knowledge that decreases in students' heterogeneity and group size, getting to zero when the number of students is sufficiently large. Abler students are those who contribute more, and less able students are those who benefit more from public knowledge whenever its amount is positive (since they obtain more public knowledge than they contribute to).

The first testable implication of these joint assumptions is that the effort exerted in the production of both private and public knowledge is increasing in ability. The latter increases more than the former whenever $\sigma_{\alpha} n<1$, i.e. when students belong to a small and homogeneous class.

As already mentioned at the beginning of this section, the optimal amount devoted to the production of private knowledge would be even higher if the relative evaluation in class is explicitly modelled. This happens because at the margin also the density of knowledge (intuitively, the fraction of students that can be overcome by increasing one's effort by a small amount) affects the choice, making individual learning more rewarding. ${ }^{8}$

We define a learning approach as cooperative when a larger amount of time is devoted to the production of public knowledge than of the private one:

$$
s_{i}^{*}>p_{i}^{*}
$$

\footnotetext{
8 This amounts to adding in (1) a term like $\beta \int_{0}^{p_{i}} f(p(\alpha)) d \alpha$, summarizing that the student experiences a higher utility proportional to the fraction of fellows with a lower level of private knowledge, given that public knowledge is the same for everybody. If only the relative evaluation matters, on the other hand, such a term should replace the private knowledge term in (1).
} 
A necessary condition to always observe a cooperative behaviour at individual level is $\sigma_{\alpha} n<1$, i.e. to belong to an extremely small and homogeneous class. Notice that when this condition is satisfied, all students in the group display a cooperative behaviour regardless of their ability level.

Therefore, to avoid this trivial solution of the model as well as to ensure that group learning has a fostering effect on knowledge we assume that:

$$
\frac{1}{n}<\sigma_{n}<1
$$

Could we expect to observe a degree of cooperation larger than that implied by self-interest? The answer is positive, if we modify individual preferences, for instance assuming that students enjoy cooperative learning because of the opportunity of interacting with their classmates. Moreover, a selfish behaviour in terms of learning is likely to be punished in terms of exclusion from the social activities inside and outside the class. We model the fact that students care about the opinion of their classmates turning our model into a psychological game in which opponents' beliefs enter the utility function:

$$
U_{i}=\alpha_{i} p_{i}+\tilde{s}-\frac{1}{2}\left(p_{i}\right)^{2}-\frac{1}{2}\left(s_{i}\right)^{2}-\mu\left(p_{i}-s_{i}\right), \quad \mu>0 .
$$

The last term indicates that a cooperative learning approach $s_{i}>p_{i}$ generates a good reputation among the classmates, therefore implying a positive utility, while the opposite holds when a competitive learning approach $p_{i}>s_{i}$ is chosen. ${ }^{9}$

If students do not care about the relative evaluation but only about the level of knowledge, the optimal amounts become respectively:

$$
\begin{gathered}
\underset{p_{i}}{\arg \max }\left[U_{i}\right]=p_{i}^{*}=\alpha_{\mathrm{i}}-\mu \\
\underset{s_{i}}{\arg \max }\left[U_{i}\right]=s_{i}^{*}=\frac{\alpha_{\mathrm{i}}}{\sigma_{\alpha} \mathrm{n}}+\mu .
\end{gathered}
$$

The opinion of classmates, modelled in this simple way, has the effect of shifting time from competitive to cooperative learning without changing the overall amount of time devoted to studying. Both $p_{i}^{*}$ and $s_{i}^{*}$ are still increasing in ability, the former dominating the latter since we assumed that $\sigma_{\alpha} n>1$. In other words, the incentive to cooperate does not change significantly in accordance with individual ability whenever $n$ is sufficiently large and/or the class is very heterogeneous.

\footnotetext{
${ }^{9}$ Alternatively, we might interpret the last term as an altruistic component, which ensures a positive utility when the student behaves in a cooperative manner.
} 
The threshold level of ability that divides the students characterized by a competitive learning approach from those characterized by a cooperative learning approach is obtained by equating equations (7) and (8). Competitive learning occurs for all students characterised by a level of ability:

$$
\alpha_{i}>\frac{\sigma_{\alpha} n}{\sigma_{\alpha} n-1} 2 \mu
$$

which is increasing in the strength of classmates' beliefs, and decreasing in the degree of heterogeneity $\left(\sigma_{\alpha}\right)$ and the size $(n)$ of the group.

A second testable implication of our model is therefore that ceteris paribus we expect a positive correlation between ability and propensity to adopt a competitive learning approach.

Now let us see what happens to the amount of knowledge of the whole class, as measured for instance by a standardized test that mimics the outcome of job market interviews concerning pupils from different classes/schools. We define the total knowledge $K$ of a class simply as the sum of the total knowledge acquired by each student:

$$
K=\sum_{i=1}^{n} K_{i}
$$

where $K_{i}=\alpha_{i} p_{i}^{*}+\tilde{s}$, given that individual total knowledge is the outcome of individual learning $\left(\alpha_{i} p_{i}\right)$ and shared knowledge $(\tilde{s})$. Notice that public knowledge affects the outcome of every student, irrespective of both individual participation to group activities $\left(s_{i}\right)$ and of individual ability $\left(\alpha_{i}\right)$. In this way, the public knowledge $\tilde{s}$ is counted $n$ times when computing the score of the class.

As long as the public knowledge exceeds the sum of its inputs, which in our model is ensured by the assumption that $\sigma_{\alpha}<1$, the total knowledge of a class turns out to be increasing in the degree of cooperation within the class by construction. When class (group) size is sufficiently large, i.e. $n \rightarrow \infty$, and reputation about being a cooperative person is irrelevant, i.e. $\mu=0$, a purely competitive outcome emerges with individual contribution to public knowledge going to zero: as a consequence also $\tilde{s}=0$. The total knowledge, assuming ability being uniformly distributed between zero and one, $\alpha \approx U[0,1]$, is simply

$$
K=\int_{0}^{1} k_{i} d \alpha=\int_{0}^{1} \alpha p_{i}^{*} d \alpha=\int_{0}^{1} \alpha^{2} d \alpha=\left[\frac{1}{3} \alpha^{3}\right]_{0}^{1}=\frac{1}{3} .
$$


When the opinions of classmates enter students' utility functions, affecting their propensity to cooperate, the picture changes sharply, since public knowledge becomes positive also in the case of an infinitely large group:

$$
\tilde{s}=\frac{1}{\sigma_{\alpha}} \int_{0}^{1} \alpha s(\alpha) d \alpha=\frac{1}{\sigma_{\alpha}} \int_{0}^{1} \alpha \mu d \alpha=\frac{\mu}{\sigma_{\alpha}}
$$

Similarly, total knowledge increases (given $\sigma_{\alpha}<1$ by assumption):

$$
\begin{gathered}
K=\int_{0}^{1}\left(\alpha p_{i}+\tilde{s}\right) d \alpha=\int_{0}^{1}\left[\alpha(\alpha-\mu)+\frac{\mu}{\sigma_{\alpha}}\right] d \alpha= \\
=\left[\frac{1}{3} \alpha^{3}\right]_{0}^{1}-\mu\left[\frac{1}{2} \alpha^{2}\right]_{0}^{1}+\frac{\mu}{\sigma_{\alpha}}[\alpha]_{0}^{1}=\frac{1}{3}+\frac{2-\sigma_{\alpha}}{2 \sigma_{\alpha}} \mu .
\end{gathered}
$$

The same results hold qualitatively when the number of students in the group is finite. When the incentive to cooperate is based on the individual return only, i.e. $\mu=0$, the public knowledge coming from cooperative learning is:

$$
\tilde{s}=\frac{1}{\sigma_{\alpha} n} \sum_{i=1}^{n} \alpha_{i} s_{i}=\frac{1}{\sigma_{\alpha} n} \sum_{i=1}^{n} \frac{\alpha_{i}^{2}}{\sigma_{\alpha} n}=\frac{1}{\sigma_{\alpha}^{2} n^{2}} \sum_{i=1}^{n} \alpha_{i}^{2}
$$

and total knowledge therefore is:

$$
K=\sum_{i=1}^{n}\left(\alpha_{i} p_{i}+\tilde{s}\right)=\sum_{i=1}^{n} \alpha_{i}^{2}+n \tilde{s}=\left(1+\frac{1}{\sigma_{\alpha}^{2} n}\right) \sum_{i=1}^{n} \alpha_{i}^{2}
$$

When the classmates' opinion enters students' utility functions, public knowledge increases and becomes:

$$
\tilde{s}=\frac{1}{\sigma_{\alpha} n} \sum_{i=1}^{n} \alpha_{i} s_{i}=\frac{1}{\sigma_{\alpha} n} \sum_{i=1}^{n}\left(\frac{\alpha_{i}^{2}}{\sigma_{\alpha} n}+\alpha_{i} \mu\right)=\frac{1}{\sigma_{\alpha}^{2} n^{2}} \sum_{i=1}^{n} \alpha_{i}^{2}+\frac{\mu}{\sigma_{\alpha}} \bar{\alpha}
$$

while total knowledge is also greater (since $\sigma_{\alpha}<1$ by assumption ) and equal to:

$$
\begin{gathered}
K=\sum_{i=1}^{n}\left(\alpha_{i} p_{i}+\tilde{s}\right)=\sum_{i=1}^{n}\left[\alpha_{i}\left(\alpha_{i}-\mu\right)\right]+n \tilde{s}= \\
=\sum_{i=1}^{n} \alpha_{i}^{2}-n \mu \bar{\alpha}+\frac{1}{\sigma_{\alpha}^{2} n} \sum_{i=1}^{n} \alpha_{i}^{2}+\frac{n}{\sigma_{\alpha}} \mu \bar{\alpha}=\left(1+\frac{1}{\sigma_{\alpha}^{2} n}\right) \sum_{i=1}^{n} \alpha_{i}^{2}+\left(\frac{1-\sigma_{\alpha}}{\sigma_{\alpha}}\right) n \mu \bar{\alpha} .
\end{gathered}
$$

Of course, this also translates into a higher average knowledge in the class. A third testable implication is therefore that the stronger the social preferences for cooperation, the larger the number of students who adopt a cooperative learning 
approach, the larger the amount of public knowledge produced and therefore the larger the amount of average knowledge. In other words, total knowledge should be increasing in the reallocation of effort from individual to group learning $\left(\frac{\partial K}{\partial \mu}>0\right)$.

What can affect the preferences for cooperation? In more homogeneous environments, the opinion of classmates is likely to be more relevant. The simplest way to model such a feature would be to make social preferences a (decreasing) function of students' heterogeneity $\mu\left(\sigma_{\alpha}\right) .10$ As a consequence, tracked educational systems, characterized by a more homogeneous body of students within schools (since they are often sorted by ability into tracks), should display a relatively higher degree of cooperation and a lower degree of competition.

Moreover, since we believe that group working is more productive when involving extremes that are not too far apart, we have modelled public knowledge as a decreasing function of students' heterogeneity. If this is the case, tracked educational systems should also display a higher return to aggregate cooperative behaviour.

In a nutshell what happens is that choosing the optimal amount of learning based on individual incentives only might be Pareto inferior. In fact, the investment in group learning is inefficiently low because of the free riding problem. The presence of strong preferences for cooperation within the class, as well as belonging to a small and homogeneous group, may partially overcome such an inefficiency.

Summarizing, some testable implications can be obtained from the previous model:

- the effort exerted in the production of both private and public knowledge is increasing in ability;

- the "best" students (i.e., most able) should be characterized by a competitive learning approach, while the opposite holds for the worst students;

- students' knowledge should increase with the individual competitive behaviour and with the average cooperative behaviour (while no direct effect should be associated to the private cooperative behaviour and to the average competitive behaviour);

- tracked educational systems should display a relatively higher degree of cooperation and a lower degree of competition, as well as a higher return to cooperation.

\footnotetext{
10 This prediction is for instance in line with findings in Alesina and La Ferrara (2000) that participation in social activities is lower in more unequal and heterogeneous communities.
} 


\section{Empirical Evidence}

The OECD's PISA surveys are designed to collect information on real-life competences from 15-year-old students, on a comparable cross-country base. ${ }^{11}$ These surveys are conducted every three years, and cover reading, mathematical and scientific literacy, and problem solving, with a dominant area in each wave. The 2003 wave has been conducted in 41 countries with a primary focus on mathematical literacy. The PISA survey provides an extremely rich set of explanatory variables that can be linked to students' performance, ranging from individual characteristics and family background, to characteristics of the school and of the education system.

In the PISA questionnaire there are also some questions concerning students' learning approach. Two sets of questions concern their preference for competitive learning ${ }^{12}$ and cooperative learning ${ }^{13}$ respectively, which are not mutually exclusive. In fact, it may well be that a student wants to outperform their classmates and at the same time having preferences for cooperative learning. This information about students' learning attitudes has been summarised by the OECD researchers (using principal component analysis) into two variables (COOPLRN and COMPLRN).14

How can we use the data from PISA survey to test the predictions of the model outlined in the previous section? Several assumptions are necessary in order to compare the model with the data.

11 "PISA seeks to measure how well young adults, at age 15 and therefore approaching the end of compulsory schooling, are prepared to meet the challenges of today's knowledge societies. The assessment is forward-looking, focusing on young people's ability to use their knowledge and skills to meet real-life challenges, rather than merely on the extent to which they have mastered a specific school curriculum." (PISA 2004, p.20).

${ }^{12}$ Students have to assess how much they agree with the following statements (questions n.37a$37 \mathrm{c}-37 \mathrm{e}-37 \mathrm{~g}-37 \mathrm{j})$ :

-I would like to be the best in my class in mathematics

-I try very hard in mathematics because I want to do better in the exams than the others

-I make a real effort in mathematics because I want to be one of the best

-In mathematics I always try to do better than the other students in my class

-I do my best work in mathematics when I try to do better than others.

${ }^{13}$ Students have to assess how much they agree with the following statements (question $\mathrm{n} .37 \mathrm{~b}^{-}$ 37d-37f-37h-37i):

-In mathematics I enjoy working with other students in groups

-When we work on a project in mathematics, I think that it is a good idea to combine the ideas of all the students in a group

-I do my best work in mathematics when I work with other students

-In mathematics, I enjoy helping others to work well in a group

-In mathematics I learn most when I work with other students in my class.

14 Wallace et al. 2002 show that individual understanding of student survey statements is related to the level of student achievement, and is also variable over time: "There is increasing evidence to suggest that members of a classroom do not share the same learning environment; neither do they share the same meanings for the constructs used to measure the environment." (ibidem, p.134). However, in the PISA case the statement refers to individual aptitude and not to class perception, and therefore we feel less troubled in using it. 
In our model, individual knowledge is function of individual endowments (that we termed ability) and behaviour (in terms of effort towards individual and group learning). Unfortunately, the PISA dataset does not contain any reliable proxy for innate ability. However, if we take a sufficiently broad definition of ability as anything that contributes to the child learning and that is possessed by the child before entering the school, then all family related characteristics can be considered as proxies for the (observable) component of ability. Moreover, these observable parental characteristics (e.g., education) will also be partly correlated with a child's innate ability (due to transmission of genes). Any unobservable component of ability will then end up in the residual of any regression of students' test scores on family background.

PISA surveyed students by schools and not by classes, with an average of 33 students tested per school. After excluding data from schools with less than ten students, we take school averages as the best available proxy of class averages.

We use students' test scores as a measure of the knowledge possessed by each student. ${ }^{15}$ We take students' attitudes expressed with respect to competition Vs. cooperation with other students as proxies for the allocation of their effort in the direction of individual learning or group learning, respectively. For each student in the sample we compute the average attitude in the school towards competitive and cooperative learning, excluding his/her own opinion.

From the original dataset (276,165 observations), we drop countries where the distribution of test scores is too much dissimilar from the remaining of the sample and/or there are too many missing values in family background information (101,472 cases excluded). ${ }^{16}$ By excluding individuals in schools with less than 10 students we loose other 2,694 observations. We also omit students not enrolled in the modal grade (43.269), because they could represent biased sub-samples (either in terms of ability, or in terms of attitudes toward cooperating with others, for repeating students who might face rather dissimilar peers). Finally, keeping only the observations without missing information on all the covariates we are left with 99,727 students spanning 24 countries (descriptive statistics are summarized in Table 1, while Table 2 displays the breakdown by country).

Under this set of assumptions, let us confront the predictions of our model with the empirical evidence in the data. We know from the extensive literature on student performance (see among the others Wößmann, 2003, or Ammermüller, 2005) that individual test scores are positively correlated with a bunch of variables, although scholars fiercely disagree about their causal interpretation in

\footnotetext{
15 Actually, PISA data contain five plausible values for each student, since each student was tested on a subsample of questions. We use here the average across the five plausible values.

16 The countries excluded are Brazil, France, Greece, Indonesia, Latvia, Liechtenstein, Luxembourg, Macao (China), Mexico, New Zealand, Portugal, Slovakia, Thailand, Tunisia, Turkey, Uruguay, and Yugoslavia.
} 
some cases (see for instance Hanushek, 1997, Vs. Greenwald et al., 1996, on the role played by school resources). Among such variables there are family background (parental education, index of parental socio-economic status, number of books at home, internet connected computer at home, proxy for durables possession), some proxies of school resources (instructional time, number of computers, class size) and some institutional indicators (existence of central exit examination systems, source of funding).

Let then consider learning attitudes. The theoretical model predicts that both effort exerted producing individual knowledge and time devoted to cooperation should increase with ability, therefore displaying a positive correlation. The sample correlation between the competitive and cooperative attitude is a statistically significant 0.29 .

Our theoretical model has been set up assuming that a person exhibits either a competitive learning approach (whenever $p_{i}^{*}>s_{i}^{*}$ ) or a cooperative one (in the opposite case), and that she would be more likely to adopt the former behaviour the higher her ability. However, questions concerning a student's learning approach are not mutually exclusive in the dataset. A student can display at the same time both a stronger willingness to outperform the others and a higher propensity to cooperate than another student. For this reason we have tried to capture the prevailing attitude of students by taking the difference between the two opinions. The assumption underneath is that a competitive learner is more likely to express stronger support for a competitive behaviour than for a cooperative one.

In Table 3 we have reported the correlation of this measure (COMPLRN minus COOPLRN) with two alternative definitions of family background, used to proxy the observable component of students' ability. In column 1 we have considered the highest education and occupational prestige in the parent couple; in column 2 we have replaced these two attributes with an aggregate measure, which also contains information related to household possessions (variable ESCS - index of Economic, Social and Cultural Status). In both cases the dependent variable exhibits a positive correlation with the measures of family background, in line with the prediction of the model that the effort exerted in the production of private knowledge should be increasing in ability more than the effort exerted in group learning. We also find evidence of the fact that girls have less competitive and more cooperative attitudes than boys.

We remind the reader that the incentives to exert effort in group learning were parameterised on $\mu$ (measuring the utility impact of classmates' opinions) and $\sigma_{\alpha}$ (the heterogeneity in students' abilities). We argued that in more homogeneous environments social control is stronger, and students should therefore care more about the perception of their behaviour by other classmates. If tracked educational systems can be thought as characterised by higher $\mu$, then we should observe the prevalence of less competitive attitudes and more 
cooperative ones in such countries. ${ }^{17}$ In the data, we find evidence consistent with this prediction. There are significant cross-country variations in this attitude, as captured by the estimated country fixed effects, which are also reported in graphical form in Figure 1. Cooperative attitudes seem to be prevalent among Nordic countries (Sweden being an exception), while competitive attitudes dominate in Anglo-Saxon and Eastern Asian countries. 18 Moreover, cooperative learning is more frequent among countries adopting a tracked educational system.However, we cannot properly test for the presence of different levels of cooperation/competition across countries. The reason is that countries may differ on many other dimensions (including religion, cultural attitudes, strength of family ties, etc.), which may affect the average degree of cooperation/competition over and above the type of educational system. Hence, this drawback prevents us from safely interpreting as supporting evidence for our model the fact that most of the countries characterized by tracked educational systems exhibit low fixed effects in Figure 1, where the dependent variable is the difference between the competitive and the cooperative behaviour.

We now consider the correlation between acquired knowledge, individual ability and competitive/cooperative attitudes. In Table 4 we report OLS estimates of the correlation of students test scores, measures of family background and our measure of attitudes. Country fixed effects are included; heteroskedastic robust standard errors are clustered by school.

In column 1 we consider the individual attitudes toward competition/cooperation, in column 2 we consider the school averages (computed excluding his/her own attitude) and finally in column 3 we include both individual and school-level measures. We are not surprised to find that the test score displays a positive association with alternative measures of family background (including parental education, parental occupational prestige, computer facilities and books at home, possession of durables). We also include a proxy of individual effort, which is given by the amount of hours per week spent on "Homework or other study set by your teachers". Thus the individual level of knowledge is positively associated with (the observable components of) ability and effort. We also include two (admittedly) imperfect proxies for the size of the relevant student group: the school size and the student/teacher ratio, since we want to see whether the incentives to cooperate decline in larger communities (i.e. the returns to cooperation are lower in large groups). When we consider individual attitudes, we find that best performing students are also those who express stronger support for individual learning, while those more in favour of group activity are also those with lower performance. In other words, an individual competitive attitude is positively associated to individual acquisition of knowledge, while a cooperative

17 We classify countries as "comprehensive" or "tracked" on the basis of whether students were attending one or more secondary school types - see footnote of Table 1.

${ }_{18}$ Curiously enough we find that Asian countries generally rank high in terms of competitive attitudes. However, despite common beliefs that Confucian heritage favours cooperation, PhuonMai et al. (2005) show that the same culture creates an obstacle to effective cooperation in learning. 
attitude shows a negative correlation with it, ${ }^{19}$ but only in comprehensive educational systems. Notice that these individual incentives to compete are strengthened in larger communities (higher student/teachers) and/or in more heterogeneous environments (school systems that are not tracked). This is in line with the prediction of the model that since tracked educational systems are characterized by a lower heterogeneity they should also display a higher return to cooperative attitudes.

More surprising are the correlations with school-level (i.e. collective) attitudes reported in column 2 of Table 4 . Here we observe a reversal of signs. Other things being constant, students in schools where competitive attitudes are prevalent obtain lower knowledge, while the opposite situation is observed when cooperative attitudes towards learning occur. When considering the institutional features of a country, we observe that the average competitive attitude is associated to a slightly more negative premium in comprehensive systems, while the reward to the prevalence of average cooperative attitudes is twice as large in tracked educational systems. If we consider that tracked educational systems are more homogeneous in terms of student abilities (since tracking is usually done according to children's potential ability and past school performance) our results suggest that cooperation is more convenient among classmates that are more similar one to each other.

In column 3 of Table 4 we combine both individual and collective attitudes, and both sets of results are confirmed. Results therefore remind us a hawk-dove game insofar as it pays being competitive while all the others are cooperative, because one obtains the benefit both of the private good (individual learning) and of the public good (the public knowledge). Unlike the hawk-dove game, however, this is not an anti-coordination game. In contrast, all students end up doing the same thing in equilibrium, namely investing an inefficiently low amount of time in the production of public knowledge. This situation is quite consistent with the results of our theoretical model, in which individual knowledge increases with individual competitive behaviour and with average cooperative behaviour. However, the model does not consider negative externalities from the average competitive behaviour (which for instance could be rationalized by means of sabotage), and it does not predict a negative impact of individual cooperative behaviour.

As to the results concerning aggregate behaviour, we know from other studies (Hanushek and Wößmann, 2006) that a tracked educational system has a negative impact on average students' performance. However, in these studies it is sometimes hard to identify the effect of tracking due to the potential correlation with other unobserved country characteristics. In this respect, we include country fixed effects in our analysis (which partly capture intercept effects of tracking and country-level unobservables) while investigating the differential effect of tracking on students' performance via its interaction with student's level of cooperation. We find that test scores are higher when average cooperation is

\footnotetext{
${ }^{19}$ Notice that there is no causal implication in these correlations, because in accordance with our model both variables display a spurious correlation with the unobservable component of individual ability.
} 
higher, but in tracked systems only. In our view this reinforces our argument: tracked systems might be associated to a lower student performance (intercept effect), but at the same time tracking might have a positive effect on student knowledge both by increasing the level of student cooperation and by raising the return to cooperation. This means that the effect of tracking might turn out to be even more negative when these effects on student behaviour are neglected and it might even turns positive when they are accounted for. This is also consistent with the claim of the educationalists that group learning enhances intrinsic motivations, and consequently knowledge, provided that students are not too different among each other.

Finally, we want to test whether these attitudes had a different impact at different levels of student's knowledge (which is correlated to unobservable components of ability once we control for family background according to our model). In Table 5 we report quantile regressions at three points of the distribution of test scores $\left(25^{\text {th }}, 50^{\text {th }}\right.$ and $75^{\text {th }}$ percentile). Standard errors are obtained from bootstrapping (100 replications). The relevant coefficients (incorporating also the effect of the interaction with the dummy "tracking") are also plotted in Figure 2. When considering comprehensive educational systems, we observe that competitive attitudes display returns that are increasing in ability, while the opposite applies to cooperative attitudes. Thus, other things constant, the "best" students have a higher individual return to competition, while the "worst" students have lower disincentives when preferring cooperative learning. As far as tracked educational systems are concerned, incentives to individual competitive behaviour are lower but remain increasing in student performance, while disincentives for individual cooperative attitudes disappear independently of the student level of knowledge.

\section{Conclusions}

In the present paper we show another occurrence of "failure of composition". A theoretical model shows that private incentives do not necessarily coincide with public ones. In a public good game (where social knowledge represents the public good at hand) this leads to a suboptimal provision of cooperation, due to free riding incentives. The free riding problem is attenuated whenever reputation among peers is relevant for the individual and/or when heterogeneity in group abilities is limited. The first effect is obtained by means of a positive utility impact of cooperative behaviour via classmates' opinions, while the second derives from the assumption that the production of public knowledge is decreasing in heterogeneity of the group.

We then bring these implications to the data, using a survey conducted in 2003 by the OECD-PISA consortium. In this survey students express their preferences towards competitive or cooperative learning. We study the correlation between these attitudes, family background and student test scores. We show that competitive attitudes are increasing in the observable component of ability 
(parental education and occupation). In addition, even when controlling for additional aspects of family background, we show that student test scores (a reasonable proxy for knowledge) are positively correlated with competitive attitudes and negatively correlated with cooperative ones. However, the situation is reverted when we take into account the peers' attitudes: learning in a competitive environment is detrimental to knowledge, while a cooperative environment favours individual performance.

We also analyse whether these conclusions, as predicted by our model, are strengthened in more homogenous environments, which are represented by tracked educational systems. We find that tracked systems raise substantially the returns to cooperation both at individual and at aggregate level, probably thanks to a greater homogeneity of the student body.

Finally, we have investigated whether these average returns tend to vary according to the student level of performance in test scores. We find that individual incentives to compete are increasing in student performance, particularly in comprehensive educational systems. 


\section{References}

Abrami, P., Y.Lou, B.Chambers, C.Poulsen and J.C.Spence. 2000. Why Should We Group Students Within-Class for Learning? Educational Research and Evaluation 6(2): 158-179

Alesina, A., La Ferrara, E. 2000. Participation in Heterogeneous Communities. Quarterly Journal of Economics 115(3): 847-904.

Ammermüller, A. 2005. Educational Opportunities and the Role of Institutions, ZEW Discussion Paper, No. 05-44.

Bettinger, E. and R.Slonim. 2006. Patience among children, mimeo.

Betts J.R. 1998. The impact of educational standards on the level and distribution of earnings. American Economic Review, 88: 266-275.

Blumenfeld, P., R.Marx, E.Soloway and J.Krajcik. 1996. Learning with peers: from small group cooperation to collaborative communities. Educational Researcher 25(8): 37-40.

Chelonis, J., R.Flake, R.Baldwin, D.Blake and M. Paule. 2004. Developmental aspects of timing behaviour in children. Neurotoxicology and Teratology 26: $461-476$.

Cowie, H., and L. Berdondini. 2001. Children's reactions to cooperative group work: a strategy for enhancing peer relationships among bullies, victims and bystanders. Learning and Instruction. 11(6): 517-530.

Greenwald, R., L.V. Hedges e Laine (1996). "The Effect of School Resources on Student Achievement" Review of Educational Research 66(3): 361-396.

Hanushek, E.A. (1997). "Assessing the Effect of School Resources on Student Performance: An Update" Educational Evaluation and Policy Analysis 19: 141-164.

Hanushek, E. and L.Wößmann. 2006. Does Educational Tracking Affect Performance and Inequality? Differences-In-Differences Evidence Across Countries. Economic Journal 116: C63-C76.

Hänze, M. and R.Berger. 2007. Cooperative learning, motivational effects, and student characteristics: An experimental study comparing cooperative learning and direct instruction in 12 th grade physics classes. Learning and Instruction 17(1): 29-41.

Harbaugh, W and K.Krause. 2000. Children's altruism in public good and dictator experiments. Economic Inquiry 38 (1): 95-109.

Hoek, D., P.van den Eeden and J.Terwel. 1999. The effects of integrated social and cognitive strategy instruction on the mathematics achievement in secondary education. Learning and Instruction 9(5): 427-448.

Malone, T. W., \& Lepper, M. R. (1987). Making learning fun: A taxonomy of intrinsic motivations for learning. In R. E. Snow \& M. J. Farr (Eds.), Attitude, learning and instruction: III. Cognitive and affective process analyses (pp. 223-253). Hillsdale, NJ: Erlbaum.

Monk, D. (1990). Educational finance: an economic approach. New York: McGraw-Hill. 
Nichols, J. 1996. Cooperative Learning: A Motivational Tool to Enhance Student Persistence, Self-Regulation, and Efforts to Please Teachers and Parents. Educational Research and Evaluation 2(3): $224-260$.

Phuong-Mai,N., C.Terlouw and A.Pilot. 2005 Cooperative learning vs Confucian heritage culture's collectivism: confrontation to reveal some cultural conflicts and mismatch. Asia Europe Journal 3: 403-419.

PISA 2004. Learning for Tomorrow's World - First Results from PISA 2003. Paris.

Shachar, H. and S.Fischer. 2004. Cooperative learning and the achievement of motivation and perceptions of students in 11th grade chemistry classes. Learning and Instruction 14(1): 69-87.

Strijbos, J.W. and F.Fischer. 2007. Methodological challenges for collaborative learning research. Learning and Instruction 17(4): 389-393.

Wallace, J., G.Venville and C.Y. Chou. 2002. "Cooperate is when you don't fight": Students' Understandings of Their Classroom Learning Environment. Learning Environments Research 5(2):133-153.

Watkins, C. 2005. Classrooms as learning communities: a review of research. London Review of Education 3(1): $47-64$.

Wößmann, L. 2003. Schooling resources, educational institutions and student performance: the international evidence. Oxford Bulletin of Economics and Statistics, 65(2): 117-170.

Wößmann, L. 2005. The effect heterogeneity of central examinations: evidence from TIMSS, TIMSS-repeat and PISA. Education Economics, 13(2), 143-169.

Zammuner, V.L. 1995. Individual and cooperative computer-writing and revising: Who gets the best results? Learning and Instruction 5(2): 101-124. 


\section{Tables and Figures}

Table 1 - Descriptive statistics - PISA 2003

\begin{tabular}{l|ccccc} 
Variable & Obs & Mean & Std. Dev. & Min & Max \\
\hline Test score in mathematics & 99,727 & 530.403 & 84.839 & 192.740 & 848.995 \\
Female & 99,727 & 0.515 & 0.500 & 0 & 1 \\
Age & 99,727 & 15.796 & 0.287 & 15.170 & 16.420 \\
Highest parental occupational status & 99,727 & 50.417 & 16.072 & 16 & 90 \\
Highest parental education in years of schooling & 99,727 & 13.380 & 2.850 & 0 & 17 \\
Computer facilities at home & 99,727 & 0.236 & 0.893 & -1.676 & 1.051 \\
Index of home possessions & 99,727 & 0.174 & 0.922 & -3.787 & 1.940 \\
Hours All homework & 99,727 & 6.214 & 5.648 & 0 & 30 \\
How many books at home & 99,727 & 3.709 & 1.358 & 1 & 6 \\
Student/teacher ratio & 99,727 & 13.584 & 4.630 & 1.379 & 70 \\
School size & 99,727 & 707.070 & 437.801 & 19 & 6000 \\
Competitive learning & 99,727 & -0.035 & 0.966 & -2.844 & 2.450 \\
Co-operative learning & 99,727 & -0.021 & 0.967 & -3.134 & 2.742 \\
Tracking* & 99,727 & 0.471 & 0.499 & 0 & 1 \\
\hline Countric
\end{tabular}

* Countries classified as tracked according to the distribution of the type of secondary school attended (variable PROGN): Austria, Belgium, Czech Republic, Denmark, Germany, Hong Kong (China), Hungary, Ireland, Italy, Japan, Korea, Netherlands, Russian Federation, Spain

Table 2 - Countries included in the analysis - PISA 2003

\begin{tabular}{l|ccc} 
Country ID & Freq. & Percent & Cum. \\
\hline Australia & 7,491 & 7.51 & 7.51 \\
Austria & 1,863 & 1.87 & 9.38 \\
Belgium & 4,935 & 4.95 & 14.33 \\
Canada & 16,362 & 16.41 & 30.73 \\
Czech Republic & 2,684 & 2.69 & 33.43 \\
Denmark & 2,676 & 2.68 & 36.11 \\
Finland & 4,563 & 4.58 & 40.69 \\
Germany & 1,925 & 1.93 & 42.62 \\
Hong Kong (China) & 2,329 & 2.34 & 44.95 \\
Hungary & 2,362 & 2.37 & 47.32 \\
Iceland & 2,531 & 2.54 & 49.86 \\
Ireland & 1,491 & 1.50 & 51.35 \\
Italy & 8,390 & 8.41 & 59.77 \\
Japan & 3,681 & 3.69 & 63.46 \\
Korea & 4,402 & 4.41 & 67.87 \\
Netherlands & 1,229 & 1.23 & 69.10 \\
Norway & 2,767 & 2.77 & 71.88 \\
Poland & 3,937 & 3.95 & 75.83 \\
Russian Federation & 3,112 & 3.12 & 78.95 \\
Spain & 5,930 & 5.95 & 84.89 \\
Sweden & 3,583 & 3.59 & 88.48 \\
Switzerland & 4,410 & 4.42 & 92.91 \\
United Kingdom & 4,914 & 4.93 & 97.83 \\
United States & 2,160 & 2.17 & 100.00 \\
Total & 99,727 & 100.00 & \\
\hline
\end{tabular}


Table 3 - Competitive attitude and family background - PISA 2003

\begin{tabular}{|c|c|c|}
\hline & $\begin{array}{c}1 \\
\text { complrn-cooplrn }\end{array}$ & $\begin{array}{c}2 \\
\text { complrn-cooplrn }\end{array}$ \\
\hline female & $\begin{array}{c}-0,285 \\
{[36,94]^{\star \star *}}\end{array}$ & $\begin{array}{c}-0,287 \\
3718]^{* * *}\end{array}$ \\
\hline Highest parental occupational status & $\begin{array}{c}0,002 \\
{[6.20]^{* * *}}\end{array}$ & \\
\hline Highest parental education in years of schooling & $\begin{array}{c}0,008 \\
{[5.63]^{\star * *}}\end{array}$ & \\
\hline Index of socio-economic and cultural status & & $\begin{array}{c}0,052 \\
{[11.16]^{\star \star *}}\end{array}$ \\
\hline Australia & $\begin{array}{c}0,166 \\
{[7.34]^{\star \star *}}\end{array}$ & $\begin{array}{c}0,344 \\
{[27.32]^{\star * *}}\end{array}$ \\
\hline Austria & $\begin{array}{c}-0,369 \\
{[7.46]^{\star * *}}\end{array}$ & $\begin{array}{c}-0,19 \\
{[4.15]^{\star * *}}\end{array}$ \\
\hline Belgium & $\begin{array}{c}-0,373 \\
{[13.58]^{\star * \star}}\end{array}$ & $\begin{array}{c}-0,193 \\
{[9.98]^{\star \star *}}\end{array}$ \\
\hline Canada & $\begin{array}{l}-0,041 \\
{[1.73]^{*}}\end{array}$ & $\begin{array}{c}0,138 \\
{[10.31]^{\star * *}}\end{array}$ \\
\hline Czech Republic & $\begin{array}{c}-0,133 \\
{[4.51]^{* * *}}\end{array}$ & $\begin{array}{c}0,049 \\
{[2.28]^{* *}}\end{array}$ \\
\hline Denmark & $\begin{array}{c}-0,349 \\
{[10.91]^{\star * *}}\end{array}$ & $\begin{array}{c}-0,163 \\
{[6.47]^{\star * *}}\end{array}$ \\
\hline Finland & $\begin{array}{c}-0,218 \\
{[7.98]^{\star * *}}\end{array}$ & $\begin{array}{l}-0,036 \\
{[1.85]^{\star}}\end{array}$ \\
\hline Germany & $\begin{array}{l}-0,101 \\
{[2.52]^{\text {}}}\end{array}$ & $\begin{array}{c}0,075 \\
{[2.08]^{* *}}\end{array}$ \\
\hline Hong Kong (China) & $\begin{array}{c}0,102 \\
{[4.38]^{\star \star \star}}\end{array}$ & $\begin{array}{c}0,284 \\
{[15.41]^{\star \star *}}\end{array}$ \\
\hline Hungary & $\begin{array}{c}-0,384 \\
{[12.55]^{\star * *}}\end{array}$ & $\begin{array}{c}-0,198 \\
{[7.95]^{\star \star *}}\end{array}$ \\
\hline Iceland & $\begin{array}{c}0,502 \\
{[13.66]^{\star \star \star}}\end{array}$ & $\begin{array}{c}0,671 \\
{[22.40]^{\star * *}}\end{array}$ \\
\hline Ireland & $\begin{array}{c}0,161 \\
{[4.01]^{\star * *}}\end{array}$ & $\begin{array}{c}0,344 \\
{[9.50]^{\star * \star}}\end{array}$ \\
\hline Italy & $\begin{array}{c}-0,196 \\
{[7.51]^{\star \star *}}\end{array}$ & $\begin{array}{l}-0,015 \\
{[0.78]}\end{array}$ \\
\hline Japan & $\begin{array}{c}0,198 \\
{[6.50]^{\star \star \star}}\end{array}$ & $\begin{array}{c}0,394 \\
{[16.98]^{\star * \star}}\end{array}$ \\
\hline Korea & $\begin{array}{c}0,67 \\
{[29.79]^{\star * *}}\end{array}$ & $\begin{array}{c}0,851 \\
{[58.93]^{\star * *}}\end{array}$ \\
\hline Netherlands & $\begin{array}{c}-0,361 \\
{[11.25]^{* * *}}\end{array}$ & $\begin{array}{c}-0,179 \\
{[6.73]^{\star * *}}\end{array}$ \\
\hline Norway & $\begin{array}{c}-0,39 \\
{[10.50]^{\star * *}}\end{array}$ & $\begin{array}{c}-0,216 \\
{[6.99]^{\star * *}}\end{array}$ \\
\hline Poland & $\begin{array}{l}-0,044 \\
{[1.81]^{*}}\end{array}$ & $\begin{array}{c}0,14 \\
{[8.42]^{\star * *}}\end{array}$ \\
\hline Russian Federation & $\begin{array}{l}-0,051 \\
{[1.87]^{*}}\end{array}$ & $\begin{array}{c}0,14 \\
{[7.25]^{\star \star *}}\end{array}$ \\
\hline Spain & $\begin{array}{c}-0,08 \\
{[3.15]^{\star \star *}}\end{array}$ & $\begin{array}{c}0,094 \\
{[4.86]^{\star * *}}\end{array}$ \\
\hline Sweden & $\begin{array}{c}0,112 \\
{[3.77]^{\star * *}}\end{array}$ & $\begin{array}{c}0,289 \\
{[12.57]^{* * *}}\end{array}$ \\
\hline Switzerland & $\begin{array}{c}-0,547 \\
{[16.32]^{\star * *}}\end{array}$ & $\begin{array}{c}-0,365 \\
{[12.60]^{\star * *}}\end{array}$ \\
\hline United Kingdom & $\begin{array}{l}0,019 \\
{[0.74]}\end{array}$ & $\begin{array}{c}0,199 \\
{[10.76]^{\star * *}}\end{array}$ \\
\hline United States & $\begin{array}{c}0,066 \\
{[2.01]^{* *}}\end{array}$ & $\begin{array}{c}0,246 \\
{[9.28]^{\star \star \star}}\end{array}$ \\
\hline Observations & 99,727 & 99,727 \\
\hline R-squared & 0.07 & 0.07 \\
\hline Log likelihood & $-152,094$ & $-152,084$ \\
\hline
\end{tabular}


Table 4 - Performance in math tests - PISA 2003

\begin{tabular}{|c|c|c|c|}
\hline & $\begin{array}{c}1 \\
\text { individual } \\
\text { attitude }\end{array}$ & $\begin{array}{c}2 \\
\text { school } \\
\text { attitude }\end{array}$ & $\begin{array}{c}3 \\
\text { individual } \\
\text { +school } \\
\text { attitude }\end{array}$ \\
\hline Female & $\begin{array}{c}-15.15 \\
{[22.51]^{\star * *}}\end{array}$ & $\begin{array}{c}-18.11 \\
{[27.64]^{\star * *}}\end{array}$ & $\begin{array}{c}-15.588 \\
{[23.47]^{* * *}}\end{array}$ \\
\hline Age of student & $\begin{array}{c}3.586 \\
{[3.76]^{* * *}}\end{array}$ & $\begin{array}{c}3.261 \\
{[3.42]^{* * *}}\end{array}$ & $\begin{array}{c}3.34 \\
{[3.52]^{\star * *}}\end{array}$ \\
\hline Highest parental occupational status & $\begin{array}{c}0.723 \\
{[36.50]^{* * *}}\end{array}$ & $\begin{array}{c}0.726 \\
{[36.60]^{* * *}}\end{array}$ & $\begin{array}{c}0.723 \\
{[36.63]^{\star * *}}\end{array}$ \\
\hline Highest parental education in years of schooling & $\begin{array}{c}1.393 \\
{[12.22]^{\star * *}}\end{array}$ & $\begin{array}{c}1.386 \\
{[12.21]^{\star * *}}\end{array}$ & $\begin{array}{c}1.35 \\
{[11.92]^{\star * *}}\end{array}$ \\
\hline Computer facilities at home & $\begin{array}{c}6.762 \\
{[15.13]^{\star * *}}\end{array}$ & $\begin{array}{c}6.832 \\
{[15.32]^{\star * *}}\end{array}$ & $\begin{array}{c}6.733 \\
{[15.10]^{* * *}}\end{array}$ \\
\hline Index of home possessions & $\begin{array}{c}6.259 \\
{[13.31]^{* * *}}\end{array}$ & $\begin{array}{c}6.646 \\
{[14.15]^{\star * *}}\end{array}$ & $\begin{array}{c}6.287 \\
{[13.46]^{* * *}}\end{array}$ \\
\hline Hours All homework & $\begin{array}{c}1.354 \\
{[19.24]^{* * *}}\end{array}$ & $\begin{array}{c}1.517 \\
{[22.26]^{\star * *}}\end{array}$ & $\begin{array}{c}1.358 \\
{[19.79]^{* * *}}\end{array}$ \\
\hline How many books at home & $\begin{array}{c}12.276 \\
{[48.09]^{\star * *}}\end{array}$ & $\begin{array}{c}12.208 \\
{[48.08]^{\star \star \star}}\end{array}$ & $\begin{array}{c}12.19 \\
{[48.17]^{\star \star *}}\end{array}$ \\
\hline Teacher/student ratio & $\begin{array}{l}-0.307 \\
{[1.82]^{*}}\end{array}$ & $\begin{array}{c}-0.234 \\
{[1.43]}\end{array}$ & $\begin{array}{c}-0.236 \\
{[1.43]}\end{array}$ \\
\hline School size & $\begin{array}{c}0.015 \\
{[9.02]^{* * *}}\end{array}$ & $\begin{array}{c}0.014 \\
{[8.62]^{\star * *}}\end{array}$ & $\begin{array}{c}0.014 \\
{[8.61]^{* * *}}\end{array}$ \\
\hline Competitive attitude & $\begin{array}{c}6.414 \\
{[5.58]^{\star \star *}}\end{array}$ & & $\begin{array}{c}8.928 \\
{[9.56]^{* * *}}\end{array}$ \\
\hline Co-operative attitude & $\begin{array}{c}-5.712 \\
{[5.35]^{\star * *}}\end{array}$ & & $\begin{array}{c}-6.651 \\
{[7.46]^{\star \star *}}\end{array}$ \\
\hline Competitive attitude $x$ schoolsize & $\begin{array}{l}0.001 \\
{[0.95]}\end{array}$ & & $\begin{array}{c}0 \\
{[0.00]}\end{array}$ \\
\hline Cooperative attitude $x$ schoolsize & $\begin{array}{r}-0.001 \\
{[1.15]}\end{array}$ & & $\begin{array}{l}-0.001 \\
{[0.78]}\end{array}$ \\
\hline Competitive attitude $\mathrm{x}$ student/teacher ratio & $\begin{array}{c}0.251 \\
{[3.12]^{* * *}}\end{array}$ & & $\begin{array}{c}0.128 \\
{[1.99]^{* *}}\end{array}$ \\
\hline Cooperative attitude $x$ student/teacher ratio & $\begin{array}{l}-0.028 \\
{[0.37]}\end{array}$ & & $\begin{array}{l}0.011 \\
{[0.17]}\end{array}$ \\
\hline Competitive attitude $\mathrm{x}$ tracking & $\begin{array}{c}-3.276 \\
{[4.84]^{\star * *}}\end{array}$ & & $\begin{array}{c}-3.474 \\
{[6.01]^{\star * *}}\end{array}$ \\
\hline Cooperative attitude $\mathrm{x}$ tracking & $\begin{array}{c}6.913 \\
{[11.43]^{\star * *}}\end{array}$ & & $\begin{array}{c}6.487 \\
{[11.75]^{\star * *}}\end{array}$ \\
\hline school average competitive attitude & & $\begin{array}{l}-35.749 \\
{[5.46]^{* * *}}\end{array}$ & $\begin{array}{c}-39 \\
{[6.01]^{\star * *}}\end{array}$ \\
\hline school average cooperative attitude & & $\begin{array}{l}15.822 \\
{[2.30]^{* *}}\end{array}$ & $\begin{array}{c}18.57 \\
{[2.75]^{\star \star *}}\end{array}$ \\
\hline school average competitive $\mathrm{x}$ tracking & & $\begin{array}{l}3.024 \\
{[0.66]}\end{array}$ & $\begin{array}{l}3.643 \\
{[0.80]}\end{array}$ \\
\hline school average cooperative $\mathrm{x}$ tracking & & $\begin{array}{c}23.442 \\
{[4.52]^{\star * *}}\end{array}$ & $\begin{array}{c}20.555 \\
{[4.01]^{\star * *}}\end{array}$ \\
\hline school average competitive $\mathrm{x}$ schoolsize & & $\begin{array}{c}0.01 \\
{[2.38]^{* *}}\end{array}$ & $\begin{array}{c}0.01 \\
{[2.35]^{\star *}}\end{array}$ \\
\hline school average cooperative $\mathrm{x}$ schoolsize & & $\begin{array}{l}-0.009 \\
{[1.47]}\end{array}$ & $\begin{array}{l}-0.009 \\
{[1.46]}\end{array}$ \\
\hline school average competitive $\mathrm{x}$ student/teacher ratio & & $\begin{array}{c}1.661 \\
{[3.63]^{* * *}}\end{array}$ & $\begin{array}{c}1.594 \\
{[3.52]^{* * *}}\end{array}$ \\
\hline school average cooperative $\mathrm{x}$ student/teacher ratio & & $\begin{array}{c}-0.991 \\
{[1.97]^{\star *}}\end{array}$ & $\begin{array}{c}-1.004 \\
{[2.04]^{\star *}}\end{array}$ \\
\hline Observations & 99,727 & 99,727 & 99,727 \\
\hline R-squared & 0.25 & 0.24 & 0.25 \\
\hline Log likelihood & $-570,310.62$ & $-570,792.37$ & $-570,110.68$ \\
\hline
\end{tabular}

Robust absolute value t statistics in brackets * significant at 10\%; ** significant at $5 \%$; ${ }^{* *}$ significant at $1 \%$ errors clustered by school - country fixed effects included 
Table 5 - Performance in math tests - quantile regressions - PISA 2003

\begin{tabular}{|c|c|c|c|}
\hline & $\begin{array}{c}1 \\
q 25\end{array}$ & $\begin{array}{c}2 \\
q 50\end{array}$ & $\begin{array}{c}3 \\
q 75\end{array}$ \\
\hline Female & $\begin{array}{c}-12.577 \\
{[18.37]^{* * *}}\end{array}$ & $\begin{array}{c}-16.472 \\
{[26.22]^{\star * *}}\end{array}$ & $\begin{array}{c}-20.006 \\
{[27.13]^{\star * *}}\end{array}$ \\
\hline Age of student & $\begin{array}{l}0.312 \\
{[0.24]}\end{array}$ & $\begin{array}{c}3.818 \\
{[3.70]^{\star * *}}\end{array}$ & $\begin{array}{c}4.560 \\
{[3.58]^{\star * *}}\end{array}$ \\
\hline Highest parental occupational status & $\begin{array}{c}0.763 \\
{[27.35]^{\star * *}}\end{array}$ & $\begin{array}{c}0.752 \\
{[30.04]^{\star * *}}\end{array}$ & $\begin{array}{c}0.669 \\
{[27.53]^{\star \star *}}\end{array}$ \\
\hline Highest parental education in years of schooling & $\begin{array}{c}1.365 \\
{[10.69]^{\star * *}}\end{array}$ & $\begin{array}{c}1.452 \\
{[12.30]^{\star * *}}\end{array}$ & $\begin{array}{c}1.477 \\
{[9.90]^{\star * *}}\end{array}$ \\
\hline Computer facilities at home & $\begin{array}{c}7.032 \\
{[12.59]^{\star * \star}}\end{array}$ & $\begin{array}{c}6.978 \\
{[14.06]^{\star * *}}\end{array}$ & $\begin{array}{c}6.963 \\
{[13.71]^{\star \star *}}\end{array}$ \\
\hline Index of home possessions & $\begin{array}{c}7.828 \\
{[12.53]^{\star * *}}\end{array}$ & $\begin{array}{c}6.083 \\
{[11.59]^{\star * *}}\end{array}$ & $\begin{array}{c}3.959 \\
{[7.66]^{* \star *}}\end{array}$ \\
\hline Hours All homework & $\begin{array}{c}1.654 \\
{[26.58]^{\star * *}}\end{array}$ & $\begin{array}{c}1.362 \\
{[24.52]^{* * *}}\end{array}$ & $\begin{array}{c}1.032 \\
{[17.02]^{\star * *}}\end{array}$ \\
\hline How many books at home & $\begin{array}{c}11.517 \\
{[41.24]^{* * *}}\end{array}$ & $\begin{array}{c}12.877 \\
{[42.64]^{\star * *}}\end{array}$ & $\begin{array}{c}13.933 \\
{[41.34]^{* * *}}\end{array}$ \\
\hline Teacher/student ratio & $\begin{array}{c}-0.252 \\
{[2.90]^{* * \star}}\end{array}$ & $\begin{array}{c}-0.300 \\
{[3.35]^{\star * \star}}\end{array}$ & $\begin{array}{c}-0.242 \\
{[2.63]^{\star * *}}\end{array}$ \\
\hline School size & $\begin{array}{c}0.014 \\
{[12.17]^{\star * *}}\end{array}$ & $\begin{array}{c}0.014 \\
{[18.82]^{\star * *}}\end{array}$ & $\begin{array}{c}0.015 \\
{[16.37]^{* * *}}\end{array}$ \\
\hline Competitive attitude & $\begin{array}{c}6.553 \\
{[4.64]^{\star \star \star}}\end{array}$ & $\begin{array}{c}9.907 \\
{[9.10]^{\star \star *}}\end{array}$ & $\begin{array}{c}12.627 \\
{[9.92]^{* * *}}\end{array}$ \\
\hline Co-operative attitude & $\begin{array}{c}-3.862 \\
{[3.44]^{* * *}}\end{array}$ & $\begin{array}{c}-7.499 \\
{[7.93]^{* * *}}\end{array}$ & $\begin{array}{c}-8.159 \\
{[6.40]^{* * *}}\end{array}$ \\
\hline Competitive attitude $\mathrm{x}$ schoolsize & $\begin{array}{l}-0.000 \\
{[0.06]}\end{array}$ & $\begin{array}{l}-0.000 \\
{[0.04]}\end{array}$ & $\begin{array}{l}-0.000 \\
{[0.64]}\end{array}$ \\
\hline Cooperative attitude $\mathrm{x}$ schoolsize & $\begin{array}{l}0.000 \\
{[0.86]}\end{array}$ & $\begin{array}{l}-0.001 \\
{[1.72]^{*}}\end{array}$ & $\begin{array}{c}-0.001 \\
{[1.6]}\end{array}$ \\
\hline Competitive attitude $x$ student/teacher ratio & $\begin{array}{c}0.126 \\
{[1.3]}\end{array}$ & $\begin{array}{l}0.094 \\
{[1.26]}\end{array}$ & $\begin{array}{l}0.071 \\
{[0.84]}\end{array}$ \\
\hline Cooperative attitude $\mathrm{x}$ student/teacher ratio & $\begin{array}{l}-0.147 \\
{[1.61]}\end{array}$ & $\begin{array}{l}0.082 \\
{[1.05]}\end{array}$ & $\begin{array}{l}0.117 \\
{[1.26]}\end{array}$ \\
\hline Competitive attitude $\mathrm{x}$ tracking & $\begin{array}{c}-1.512 \\
{[1.97]^{* *}}\end{array}$ & $\begin{array}{c}-3.786 \\
{[5.12]^{\star * \star}}\end{array}$ & $\begin{array}{c}-5.162 \\
{[7.50]^{* \star *}}\end{array}$ \\
\hline Cooperative attitude $x$ tracking & $\begin{array}{c}6.039 \\
{[7.98]^{\star \star *}}\end{array}$ & $\begin{array}{c}7.613 \\
{[11.00]^{* * *}}\end{array}$ & $\begin{array}{c}7.381 \\
{[10.55]^{\star \star \star}}\end{array}$ \\
\hline school average competitive attitude & $\begin{array}{l}-42.435 \\
{[10.8]^{\star \star *}}\end{array}$ & $\begin{array}{l}-33.110 \\
{[9.39]^{\star \star \star}}\end{array}$ & $\begin{array}{l}-32.603 \\
{[7.49]^{\star \star \star}}\end{array}$ \\
\hline school average cooperative attitude & $\begin{array}{c}14.818 \\
{[3.15]^{* * *}}\end{array}$ & $\begin{array}{c}17.480 \\
{[4.19]^{* * *}}\end{array}$ & $\begin{array}{c}24.950 \\
{[6.52]^{* * *}}\end{array}$ \\
\hline school average competitive $\mathrm{x}$ tracking & $\begin{array}{l}4.255 \\
{[1.39]}\end{array}$ & $\begin{array}{l}7.126 \\
{[2.60]^{* * *}}\end{array}$ & $\begin{array}{c}5.304 \\
{[2.02]^{* *}}\end{array}$ \\
\hline school average cooperative $\mathrm{x}$ tracking & $\begin{array}{c}19.696 \\
{[6.39]^{* * *}}\end{array}$ & $\begin{array}{c}21.563 \\
{[6.93]^{* * *}}\end{array}$ & $\begin{array}{c}21.070 \\
{[7.00]^{* * *}}\end{array}$ \\
\hline school average competitive $\mathrm{x}$ schoolsize & $\begin{array}{c}0.012 \\
{[5.32]^{* * *}}\end{array}$ & $\begin{array}{c}0.012 \\
{[5.32]^{* \star *}}\end{array}$ & $\begin{array}{c}0.012 \\
{[4.89]^{* * *}}\end{array}$ \\
\hline school average cooperative x schoolsize & $\begin{array}{c}-0.012 \\
{[4.51]^{\star * *}}\end{array}$ & $\begin{array}{c}-0.010 \\
{[3.61]^{* \star *}}\end{array}$ & $\begin{array}{l}-0.006 \\
{[1.99]^{* *}}\end{array}$ \\
\hline school average competitive $\mathrm{x}$ student/teacher ratio & $\begin{array}{c}1.626 \\
{[6.02]^{* * *}}\end{array}$ & $\begin{array}{c}0.878 \\
{[3.55]^{* * *}}\end{array}$ & $\begin{array}{c}0.962 \\
{[3.13]^{* * *}}\end{array}$ \\
\hline school average cooperative $\mathrm{x}$ student/teacher ratio & $\begin{array}{c}-0.512 \\
{[1.51]}\end{array}$ & $\begin{array}{c}-0.846 \\
{[2.88]^{\star * *}}\end{array}$ & $\begin{array}{c}-1.687 \\
{[6.49]^{* * *}}\end{array}$ \\
\hline Observations & & 99,727 & \\
\hline $\begin{array}{l}\text { Bootstrap absolute value t stati } \\
{ }^{*} \text { significant at } 10 \% ;{ }^{* *} \text { signifi } \\
\text { Country fixed }\end{array}$ & $\begin{array}{l}0.1325 \\
\text { (100 replic } \\
\text { ignificant a }\end{array}$ & $\begin{array}{l}0.1421 \\
\text { tions) } \\
1 \%\end{array}$ & 0.1447 \\
\hline
\end{tabular}


Figure 1 - Country fixed effect when predicting "competitive attitudes" - PISA 2003

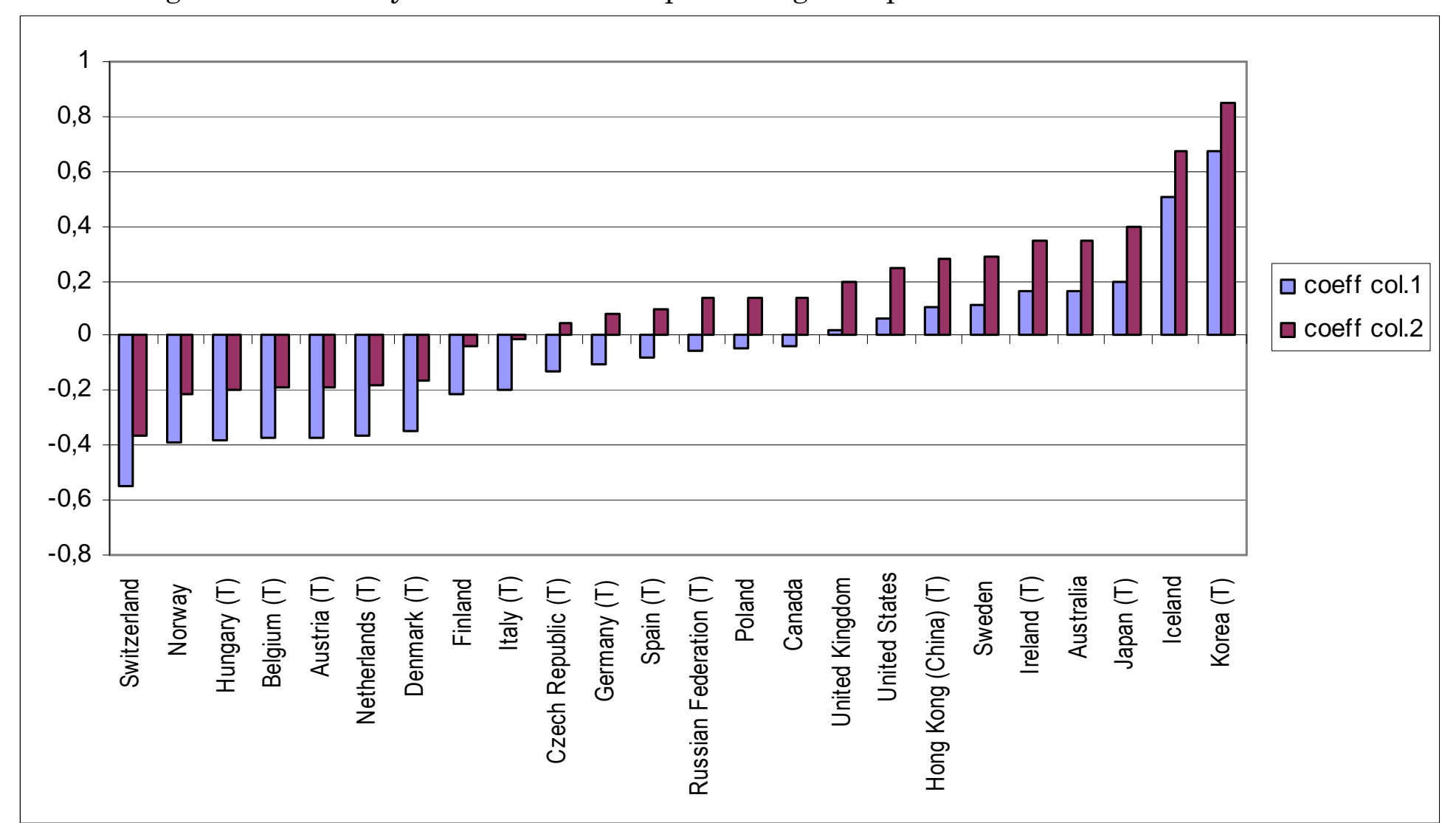

Note. The graph shows the fixed effects estimated in Table 3. (T) indicates tracked educational systems. 
Figure 2-Quantile regressions: returns to cooperative/competitive attitudes - PISA 2003
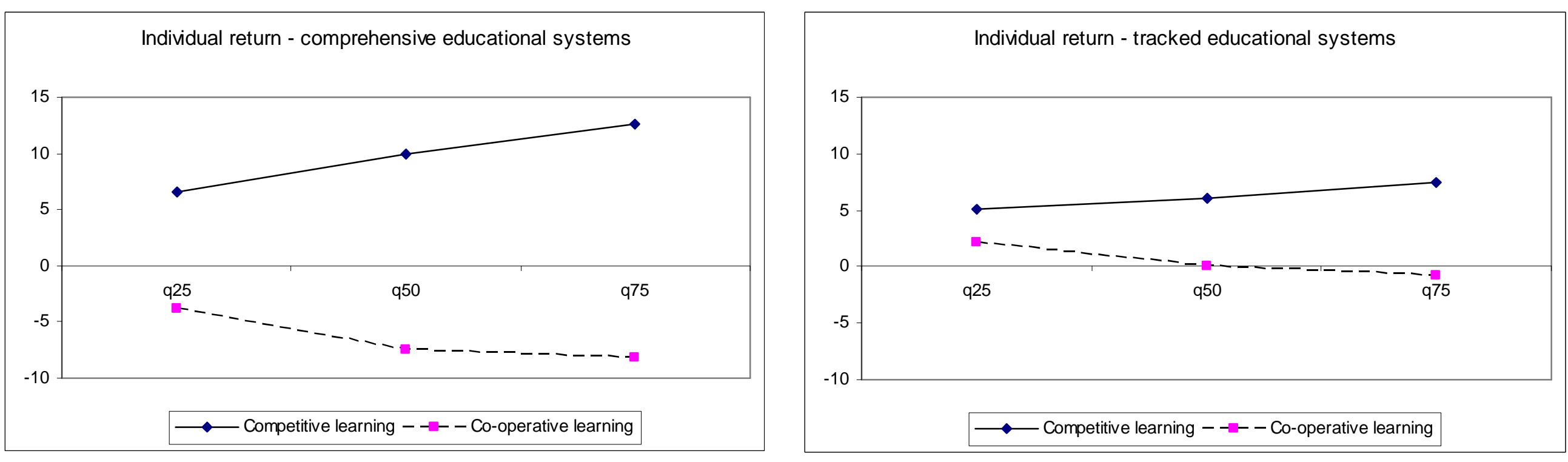